\title{
Risk management and remediation of the north wall slip, West Angelas Mine, Western Australia
}

\author{
G.G. Joass Rio Tinto Iron Ore, Australia \\ R. Dixon Rio Tinto Iron Ore, Australia \\ T. Sikma Rio Tinto Iron Ore, Australia \\ S.D.N. Wessels Rio Tinto Iron Ore, Australia \\ J. Lapwood Rio Tinto Iron Ore, Australia \\ P.J.H. de Graaf Rio Tinto Iron Ore, Australia
}

\begin{abstract}
A planar failure of approximately $600 \mathrm{kT}$ occurred on the north wall of Centre Pit North (CEPN) at West Angelas Mine site in February 2010. The failure impacted a substantial resource of high grade iron ore and left a number of significant geotechnical hazards on and adjacent to the failure surface. These presented a series of challenges which had to be overcome in order to remediate the failure and reclaim the bulk of the buried ore. A number of recovery options were investigated and presented to management. This paper outlines the plan which was adopted, the challenges encountered during its implementation and the risk management and mining procedures used to bring the remediation and recovery to a successful conclusion.
\end{abstract}

\section{Introduction}

A significant fall of ground occurred on the north wall of CEPN at the West Angelas Mine site on the evening of the 3 February 2010. The failure occurred in the Mount Newman Member of the Marra Mamba Iron Formation, which is comprised predominantly of banded iron formation (BIF) with interbedded shale. Bedding dip was roughly parallel to the overall slope angle, except where it flattened towards the pit, on the lower benches. The failure was due to planar sliding on the NS2 shale, which was daylighted in places, towards the toe of the slope. The resultant failure surface is approximately $112 \mathrm{~m}$ high, dipping at an average of $42^{\circ}$. The failed rill heap of approximately $600 \mathrm{kT}$, covered a significant resource of high grade iron ore.

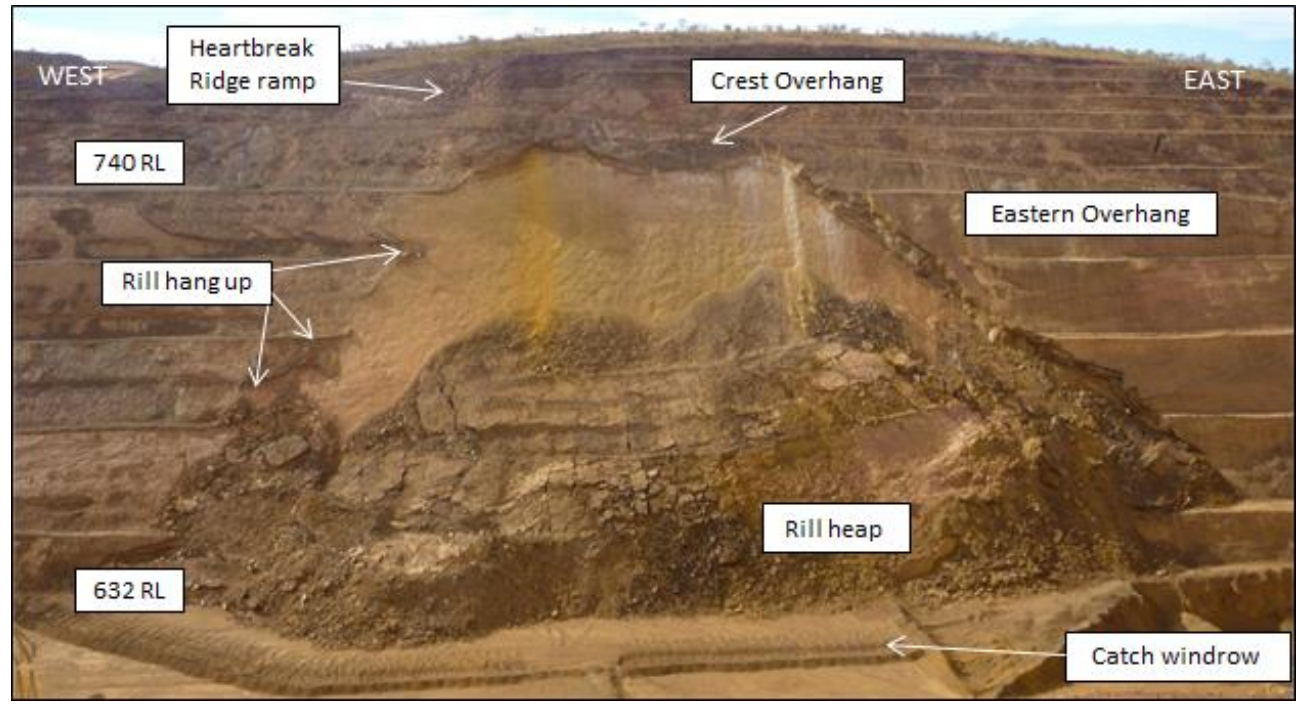

Figure 1 CEPN north wall failure and residual risks (taken 07 May 2010) 


\section{Residual risks}

Following the fall of ground, the following residual risks were identified on the slope which would need to be addressed and remediated prior to the commencement of recovery mining of the ore below (Figure 1):

- Crest overhang: A $30 \mathrm{~m}$ high, $5 \mathrm{~m}$ thick band of BIF remained across the top of the failure surface, residing on the NS2 shale.

- Eastern overhang: The break out surface on the eastern limit of the slip was defined by a sub-vertical joint plane, dipping at approximately $70^{\circ} / 230^{\circ}$, creating a significant overhang between 8 to $16 \mathrm{~m}$ thick. The NS2 shale, which formed the failure surface, extends to the east of the joint surface. It does not daylight at the toe of the eastern overhang and no potential breakout surfaces are known. Minor movements were recorded on prisms and wireline extensometers on the eastern overhang at the time of failure, however no displacements were detected post failure. The risks posed by the overhang are twofold; there is a risk of rockfalls from the underside of the overhang, and the risk of planar failure on the NS2 shale.

- Shale bedding: The NS2 shale is comprised of two shale bands 30 to $40 \mathrm{~cm}$ thick, approximately $2 \mathrm{~m}$ apart. It was initially unclear whether the failure had occurred on the upper or lower shale band, however subsequent investigations indicated it was the upper shale band. This left a veneer of BIF sitting on the lower shale band. An additional shale band (NS1.5) is located approximately $15 \mathrm{~m}$ below the NS2 shale. Both shale bands are potential slip surfaces.

- Rockfalls and hang up: A number of large rocks and areas of rill remained perched on the slip surface, and ongoing creep in the rill heap left additional suspended material on the face.

Two additional challenges were identified early in the project.

- Several large, potentially intact slabs of BIF remain within the rill heap. It was assumed that some degree of drilling and blasting would be required to reduce them to a manageable size.

- The failure plane on the NS2 shale partially daylighted above the 644 RL berm. This berm was covered by the failure. Although some damage was visible on the western side, it was unclear the extent of the intact section which would require additional drilling and blasting.

\section{Remediation planning}

Given the significant high grade ore reserves below the failed material on the $632 \mathrm{RL}$, remediation options were developed to facilitate the safe recovery of ore. Four remediation options were presented to Mine Management (Figure 2):

- No remediation of the failed material and a conservative standoff from the western margin of the slip. Lowest risk option, but would sterilise all ore in front of the slip.

- No remediation of the failed material, develop an appropriate stand-off from the toe of slip including a significant rockfall protection windrow, and an exclusion zone below the eastern overhang. This would sterilise ore beneath the eastern overhang.

- Mine out the slip debris from the west of the overhang, remediate remaining crest overhang and manage the rockfall hazard. Options for managing the rockfall hazard would involve scaling, meshing and development of catch fences. This option would sterilise ore immediately beneath the eastern overhang but would facilitate mining to a modified Life of Mine design to the east.

- Remediate the eastern overhang and mine out all of the slip material, allowing $100 \%$ ore recovery. Two options were provided for remediation of the eastern overhang:

$\circ$ Reinforcement.

- Excavation through a slope cutback. 


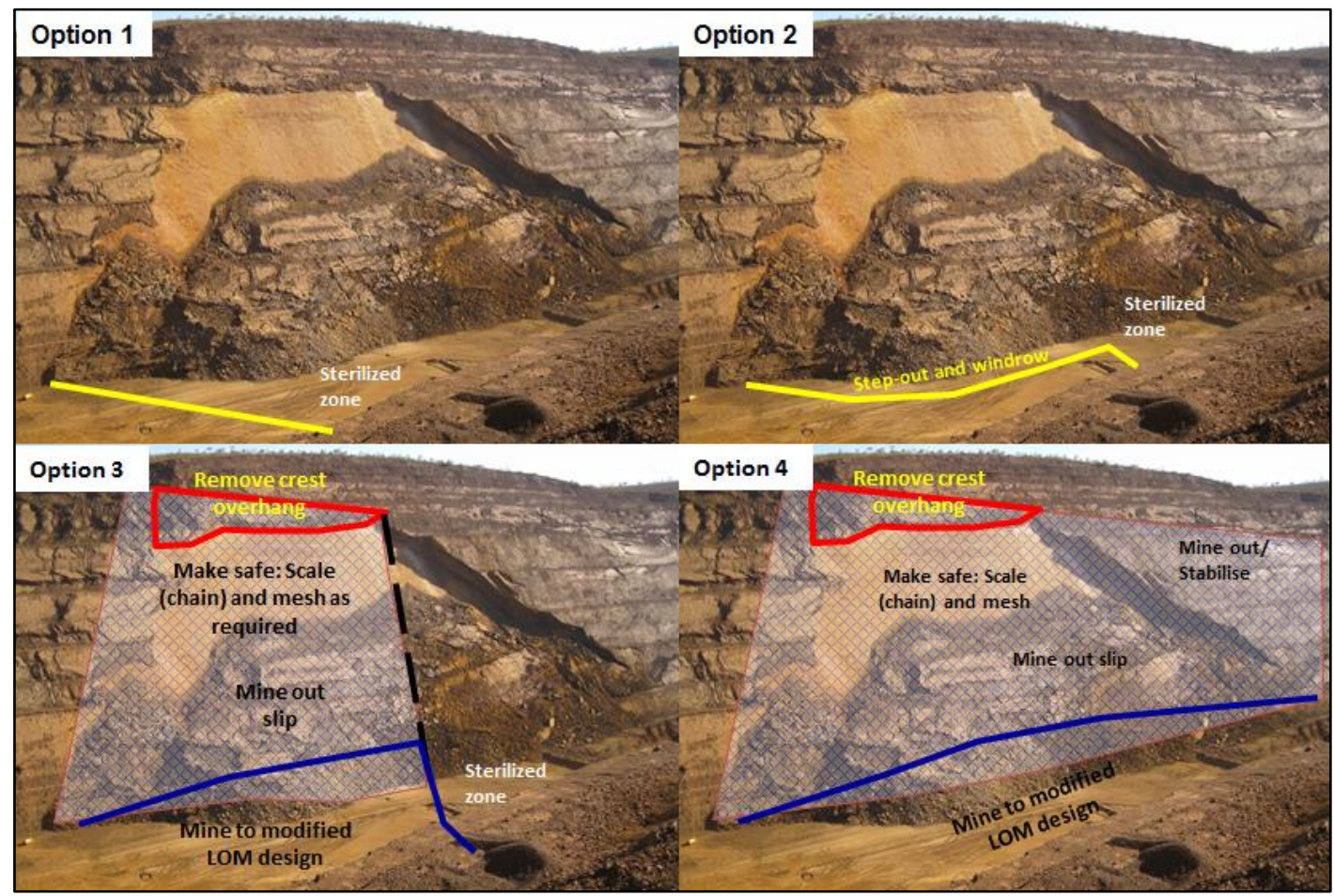

Figure 2 CEPN north wall remediation options

Stability and rockfall assessments were conducted for each option and a risk ranking for each was provided to management to make an informed decision. The risk ranking considered the following elements:

- Implementation: safety aspects along with practicality.

- Long term outcomes: operational safety and ore sterilisation (Table 1).

Option 4 was dismissed due to the high safety risk and the associated practical difficulty of stabilising the eastern overhang. Options 2 and 3 were selected as favourable scenarios, with option 3 ultimately selected. This option would involve addressing the rockfall hazards associated with the crest overhang and the slip face below.

Table 1 Option analysis

\begin{tabular}{|c|c|c|c|c|}
\hline \multirow{3}{*}{ Option } & \multicolumn{4}{|c|}{ Risk Ranking } \\
\hline & \multicolumn{2}{|c|}{ Implementation } & \multicolumn{2}{|c|}{ Long Term } \\
\hline & Safety & Practicality & Operational Safety & Ore Loss (Mt) \\
\hline 1 & NA & NA & Low Risk & $\begin{array}{l}2.8 \text { (partially } \\
\text { recoverable) }\end{array}$ \\
\hline 2 & $\begin{array}{l}\text { Moderate rockfall } \\
\text { hazard }\end{array}$ & Easy & $\begin{array}{l}\text { Low / moderate } \\
\text { rockfall hazard }\end{array}$ & 1.4 \\
\hline 3 & $\begin{array}{c}\text { High/critical rockfall } \\
\text { hazard }\end{array}$ & Difficult & Low risk & 0.6 \\
\hline \multirow[t]{2}{*}{4} & Critical to high risk & Not feasible (A) & Moderate risk & 0 \\
\hline & & Very difficult (B) & & \\
\hline
\end{tabular}




\subsection{Accepted remediation option}

Initial work was completed by Mine Operations to remove the remaining crest overhang. This was successful in reducing the volume, however did not fully remove the overhang. Following this work, several options were provided by specialist contractors to address the remaining rockfall risks. These included the use of scaling, drape and pinned meshing and rockfall fence techniques. The accepted tender involved the following steps, and is presented in detail by Lopes and Lee (2013):

1. Installation of mesh over the crest overhang and pinning the mesh to the slope with rockbolts.

2. Scaling of lower slope once the crest overhang is addressed.

This option provided a single-pass approach, which would fully contain the problem at the crest, negating the need for rockfall protection lower down the slope. Installation involving rope access with the assistance of cranes was recommended by the contractor, based on their previous experience. This method of installation had not previously been used at a Rio Tinto Iron Ore (RTIO) operation and hence management engagement was critical throughout the remediation planning and tender process, in order to gain approval for its use.

An option to use remote controlled dozers to sidecast material from the rill heap beneath the eastern overhang was also presented, as this had the potential to further increase the amount of ore recovered.

The steps involved in the final remediation plan were:

1. Remove as much of the crest overhang as possible and scale the crest (mine operations).

2. Scale and mesh the remains of the crest overhang (specialist contractor).

3. Install additional slope monitoring; prisms and time-domain reflectometry (TDR) sensors in the face (specialist contractor).

4. Scale lower slope rockfall hazards (specialist contractor).

5. Excavate a ramp at the western end to the upper part of the failed rill pile (mine operations).

6. Working west to east, excavator to sidecast the upper rill pile until a pad is established wide enough to be mined (mine operations).

7. Remote dozer to be used beneath the eastern overhang (mine operations).

Following confirmation of the remediation plan, the slope design was re-evaluated. Slope stability and rockfall mitigation controls required that the slope was modified for mining below the $632 \mathrm{RL}$ to include:

- $15 \mathrm{~m}$ wide berm between the base of the rill pile and the $632 \mathrm{RL}$ crest below.

- Lower batters must follow bedding dip $\left(40^{\circ}\right)$ as undercutting of bedding would compromise the design objectives.

\section{$4 \quad$ Remediation}

\subsection{Exclusion zones}

Before work could commence, four exclusion or 'no go' lines needed to be defined, to limit access to high risk areas (Figure 3).

- Exclusion zone 1: Pit floor $632 \mathrm{RL}$. Shortly after the failure a catch windrow $2 \mathrm{~m}$ high was constructed $15 \mathrm{~m}$ from the toe of the rill heap as protection in the event of further falls of ground. Since blasting, scaling and sidecasting at the crest has the potential to generate rockfalls, the $632 \mathrm{RL}$ bench below the slip was isolated prior to commencement of work on the face. 
- Exclusion zone 2: Crest overhang. Defined as $5 \mathrm{~m}$ to the north of the NS2 shale band for heavy equipment and $2 \mathrm{~m}$ for light vehicles and unsecured personnel on foot. A small windrow was subsequently constructed along the 'no go' line at the crest.

- Exclusion zone 3: Heartbreak Ridge ramp. Defined as $5 \mathrm{~m}$ north of the shale line. A windrow was constructed along the 'no go' line as a physical barrier against access at the crest.

- Exclusion zone 4: The eastern overhang. Defined $2 \mathrm{~m}$ west of the top of the eastern overhang to be used as protection against potential rockfall hazards. It was not designed to provide protection against a failure of the overhang itself, as this was likely to have a lateral component, to the west. This line was subsequently painted on the face by the specialist contractor and downloaded into the Computer Aided Earthmoving System (CAES, an on board monitoring system) in all manned equipment used during mining operations.

These areas were defined with use of laser scanning and photogrammetry to accurately model the failure surface and project it onto the topographic surface. Field mapping of the shale beds was also completed in a series of trenches perpendicular to the crest to better define the NS2 shale location.

Additional face scans were taken throughout the project, as more of the face was exposed and the size and shape of the rill heap changed. Photographs were also taken daily and used to chart progress for planning.

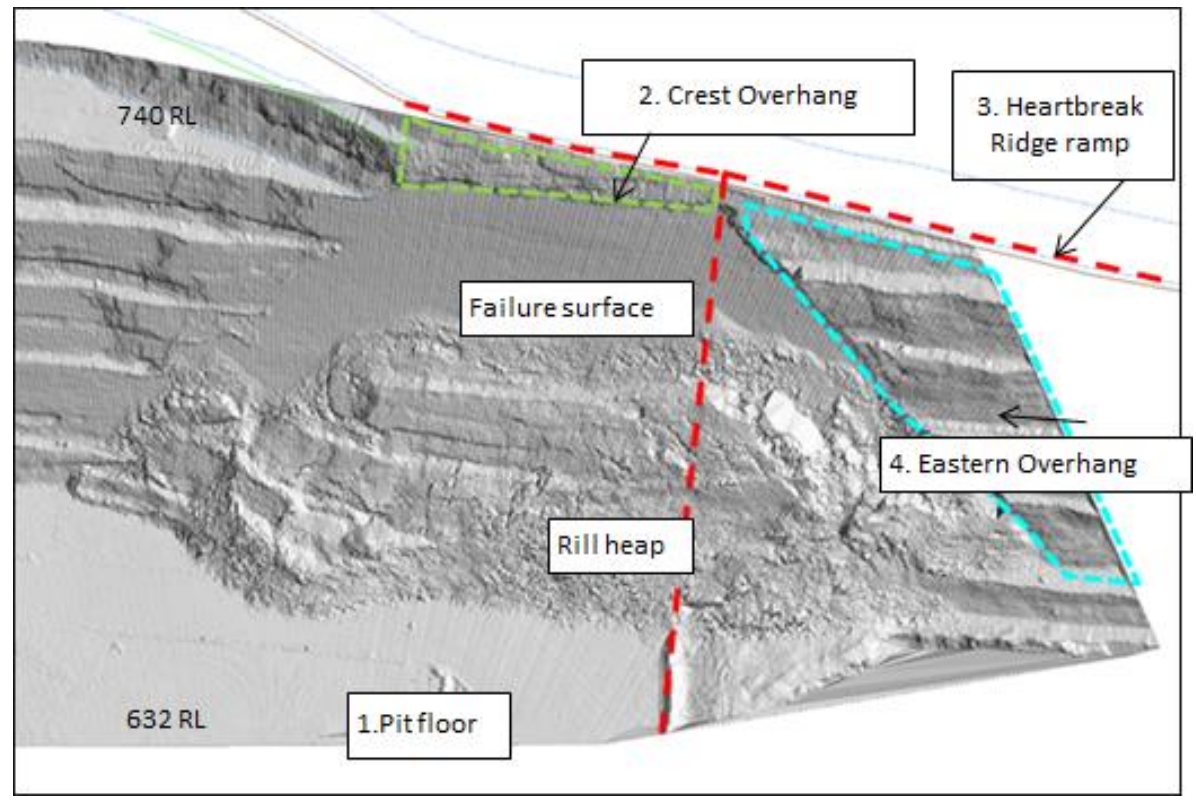

Figure 3 Laser scan of CEPN north wall failure with 'no go' lines denoted in dark red (oblique view), February 2010

\subsection{Crest overhang remediation}

\subsubsection{The 764 RL cutback}

A minor cutback was completed to remove a section of the crest overhang and reduce the area requiring meshing and scaling. By limiting the width of the cutback it was possible to retain vehicle access on the Heartbreak Ridge ramp, behind the cutback. All work was carried out under a Job Hazard Analysis (JHA). Identified controls included limiting work hours to daylight only, maintenance of the 'no go' lines, and radar monitoring of the face and overhang.

Access to the cutback for mapping was limited because of the limited size of the cutback and equipment operating in the area. A small number of points on the NS2 shale were identified, surveyed and used to further refine the NS2 shale location. They also supported the view that the failure had occurred on the 
upper NS2 shale, and that the exposed failure surface was probably a veneer 2-3 m thick, sitting on the lower shale band.

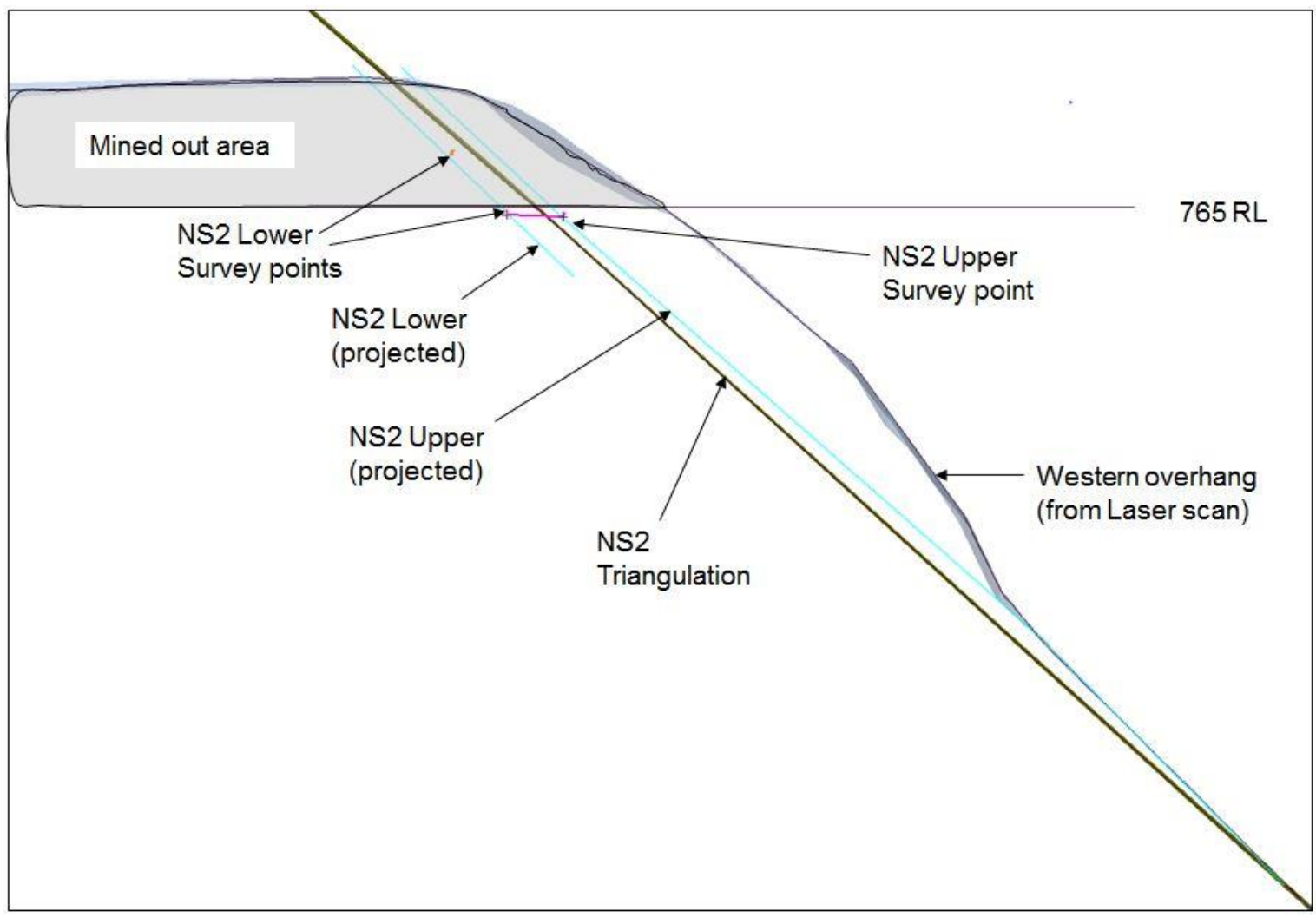

Figure 4 NS2 shale interpretation, cross section of western end of crest overhang

\subsubsection{Crest overhang removal}

A number of methods were used in an attempt to remove the crest overhang, with varying degrees of success.

- Chaining: The crest was chained with aid of an excavator, however the hard nature of the BIF meant that chaining had little impact.

- Excavator: After completion of the cutback, the excavator was used to attempt to break through the crest overhang, at its weakest point towards the eastern end. If successful it was thought the excavator could then use the weight of the remaining overhang as leverage, to help shear off the remainder. This effort was unsuccessful, with the excavator unable to dig through the overhang, nor apply sufficient pressure to induce failure in compression or tension.

- Air blasting: It was thought that the vibration caused by an air blast might shake the overhang loose. Bags of explosives were lowered on to the outside face of the overhang by crane and tied into position. A spotter on the south wall of the pit assisted with the positioning of the explosives (refer to Figure 5(a) and (b)). This was also unsuccessful.

- Pre-splitting: A pattern of drill holes was designed to provide a pre-split line along the NS2 shale. The laser scan of the face was used to determine hole depths and reduce the risk of breakout. Holes were loaded with solid explosive sausages to further reduce the risk of loss. This blast was successful, and the bulk of the crest overhang was removed. The overhang area was then cleaned further by chaining. 


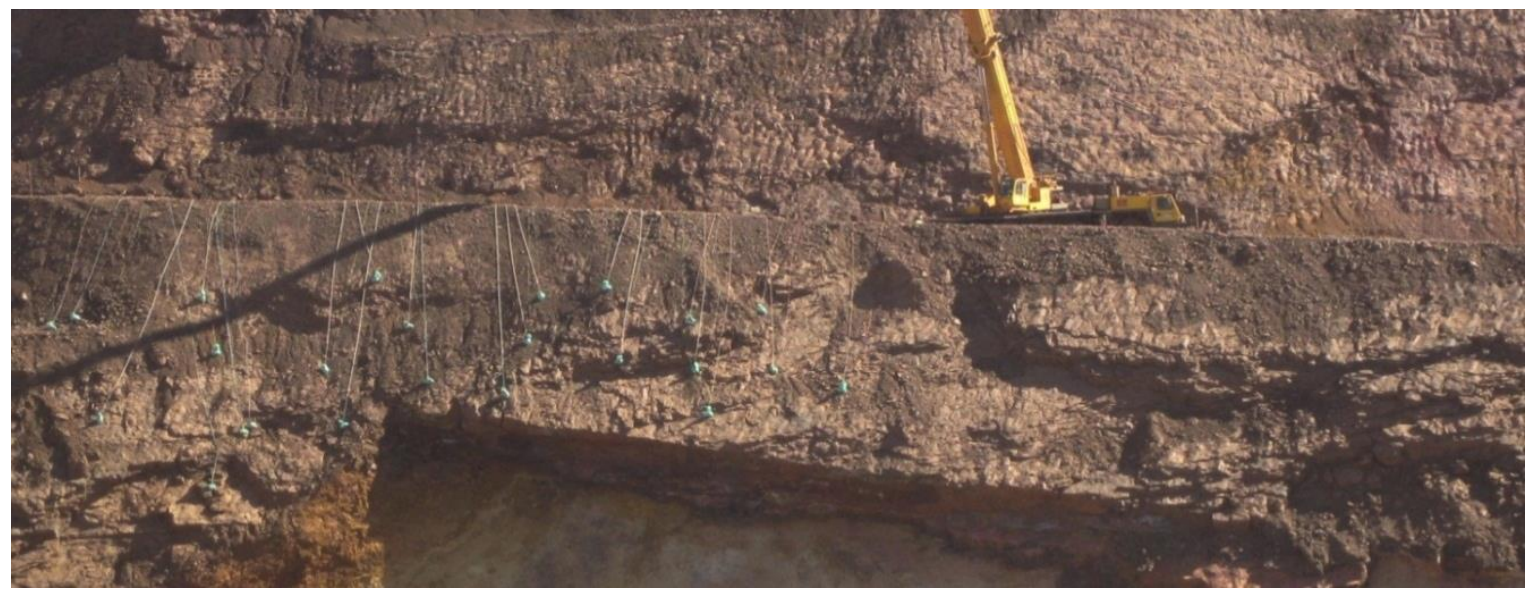

Figure 5(a) Placing explosives on crest overhang

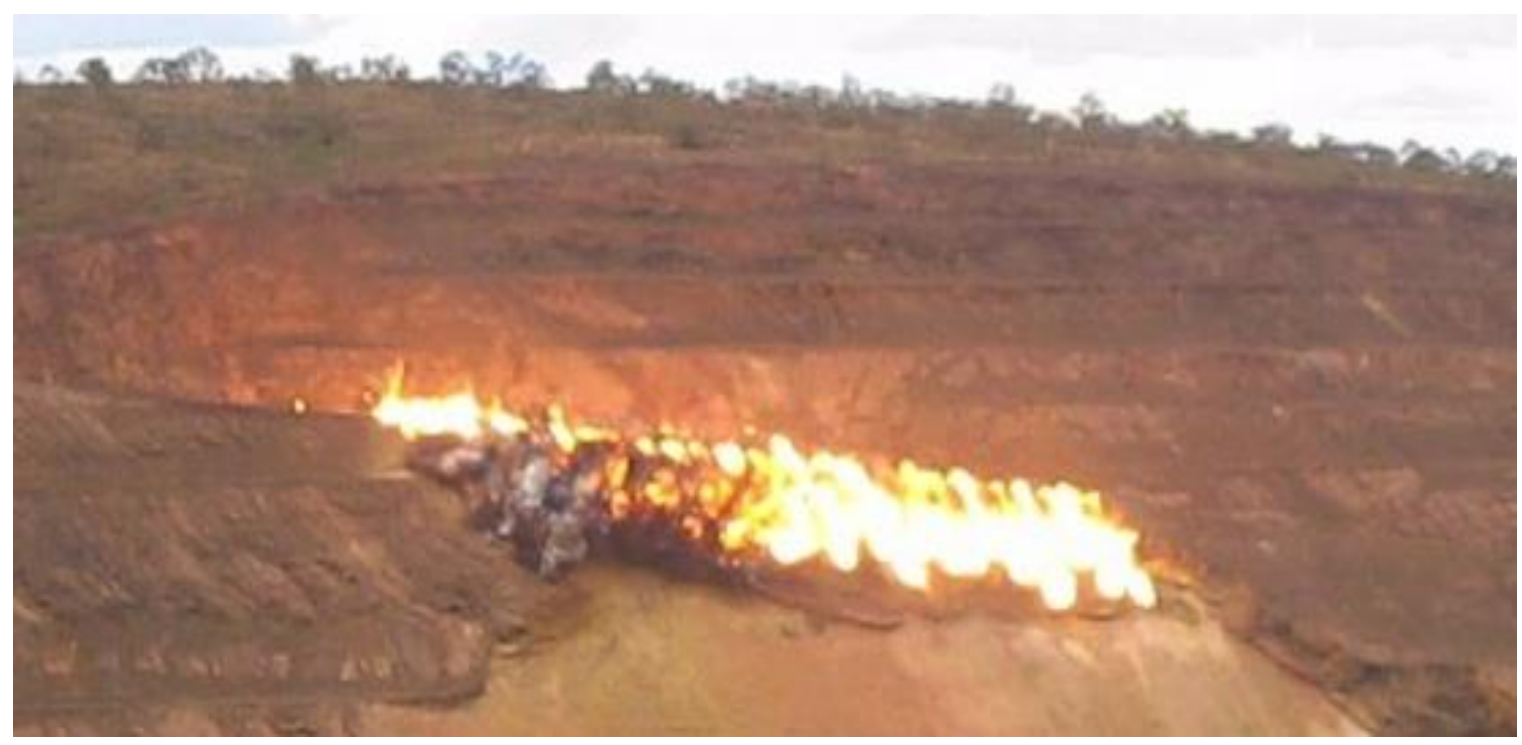

Figure 5(b) Air blast on the crest overhang

\subsection{Crest stabilisation works}

The remains of the crest overhang still posed a potential rockfall hazard, though on a much lesser scale. The remaining hazards were controlled by meshing and rock bolting by the contractor (Figure 6).

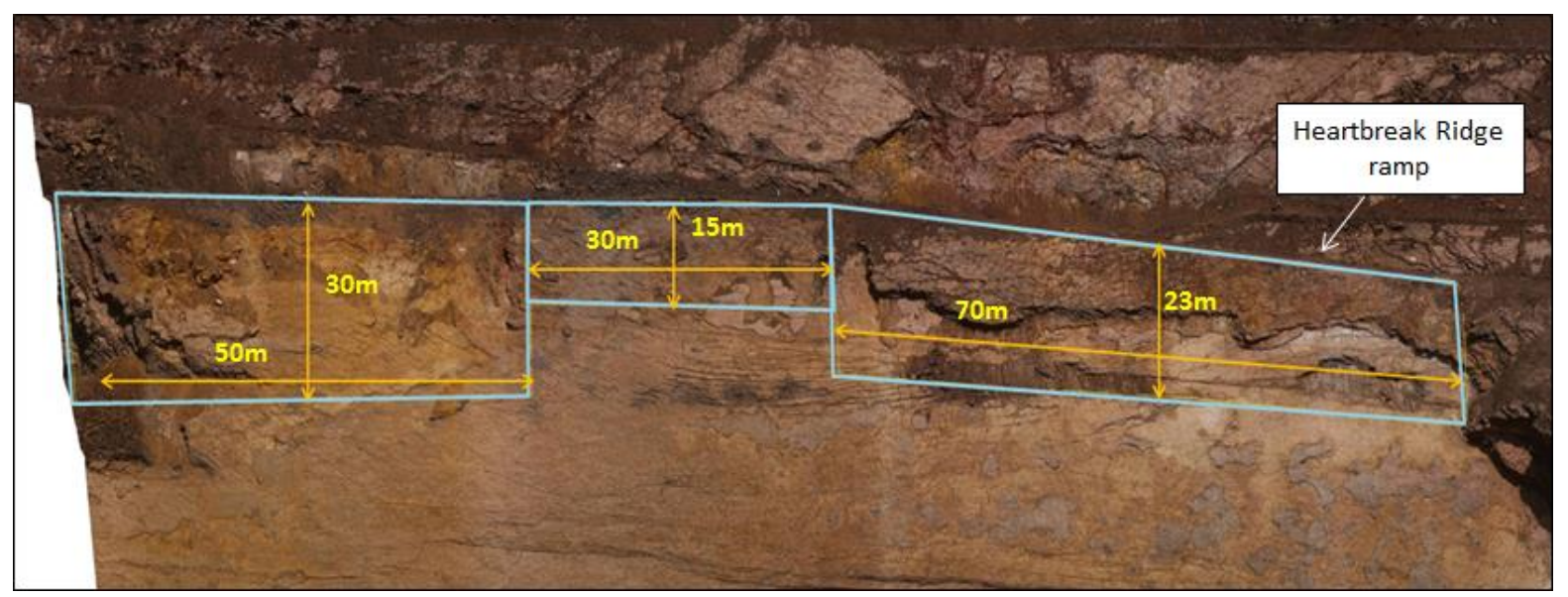

Figure 6 Remnant crest overhang and meshing requirements 


\subsubsection{Risk assessment}

An extensive level 2 risk assessment was conducted prior to commencement of the meshing project. The objective was to break the task down into steps, identify the hazards associated with each step, ensure appropriate controls were in place and assess the residual risks. The intention was to ensure that the contractor carried out all work to RTIO standards, or above. Key geotechnical controls identified included the following:

- Stability monitoring of the eastern overhang and the failure surface, using radar and autonomous prism monitoring with alarm systems operating through the RTIO Operations Centre.

- Additional prisms to be installed on the crest to provide improved coverage, particularly with the rope work obscuring part of the radar view.

- Geotechnical engineers to produce and roll out a Trigger Action Response Plan (TARP) covering actions to be taken in the event of monitoring recording significant displacement, loss of one or both monitoring systems, significant rainfall or nearby blasting.

- 'No go' line below the eastern overhang to be provided by geotechnical engineers and clearly marked on the face and crest by the contractor.

- Geotechnical engineers to undertake a pre-start check for slope displacement and confirm the monitoring systems were fully operational and alarmed.

- Visual inspection to be carried out daily by the geotechnical engineers and a pre-shift visual inspection to be carried out by the project supervisor.

- Operations confined to daylight hours only.

- All personnel to evacuate the face during significant rain or blasting in the pit. Geotechnical engineer to review the monitoring and provide an 'all clear' before work resumes.

\subsubsection{Rope access work}

A series of vertical rockbolts were installed at $3 \mathrm{~m}$ intervals behind the windrow along the crest overhang 'no go' line. These were to be used as anchor points for the rope work. The crest was scaled to remove the largest and most dangerous of the loose material. A geofabric material was draped over the crest and held in place by the mesh and rockbolts. It was used to restrain any remaining loose material. A fence was erected outside the rope access work area to facilitate visual inspections.

Particular attention was paid to the positioning of personnel when working on the slip face, due to the risk of rocks being dislodged or equipment being dropped. Working position rules were imposed, whereby personnel on the face were not allowed to work directly below, or within the fall trajectory of other personnel or equipment (crane loads, drills, etc.) above them. Because of the width of the face, it was possible to have multiple crews working at varying tasks on different parts of the face.

\subsubsection{Scaling and meshing}

Before rockbolting and meshing could commence it was necessary to scale the face to remove any remaining rockfall hazards, loose or blast damaged areas of the face. This included a section on the western end of the crest overhang and a significant pile of rill on the $764 \mathrm{RL}$ to the west of the cutback. The contractor mainly used hand tools to pry the rocks loose, but compressed air jack hammers were available as an alternative when required.

The mesh was designed to restrain potential rock falls. Rockbolts were used to secure the mesh; they were not designed to be used as face support. The rockbolts were $3 \mathrm{~m}$ long to ensure penetration into the BIF below the lower NS2 shale bed. They were installed on a 2.5 by $2.5 \mathrm{~m}$ grid pattern covering an area of $3,560 \mathrm{~m}^{2}$. All rockbolts were fully grouted; records of grout consumption by hole were kept to indicate areas of poor rock quality. Pull out tests were performed on a representative proportion of the rockbolts to 
ensure they had achieved the designed strength. The need for meshing was vindicated when a subsequent rockfall near the crest was contained by the mesh.

Once the meshing and monitoring installation were completed on the crest, a second phase of scaling commenced lower down the face to remove all remaining rockfall hazards from the lower areas of the face, which were likely to pose a safety hazard during mining of the rill pile.

\subsubsection{Instrumentation}

Improved post slip slope monitoring included additional survey prisms and TDR cables. An additional 19 prisms were installed on the slip face, monitored from an autonomous pillar, which was alarmed through the RTIO Operations Centre in Perth.

Four TDR cables were installed on the face to provide sub-surface monitoring for the deeper NS1.5 shale band (Figure 7). All instruments were installed perpendicular to the face, to a depth of $30 \mathrm{~m}$. special brackets were manufactured and mounted at the collar of the holes to prevent tight bends and damage to the cables which were extended up the face to a monitoring point on the crest. The TDRs were read manually, on a weekly basis.
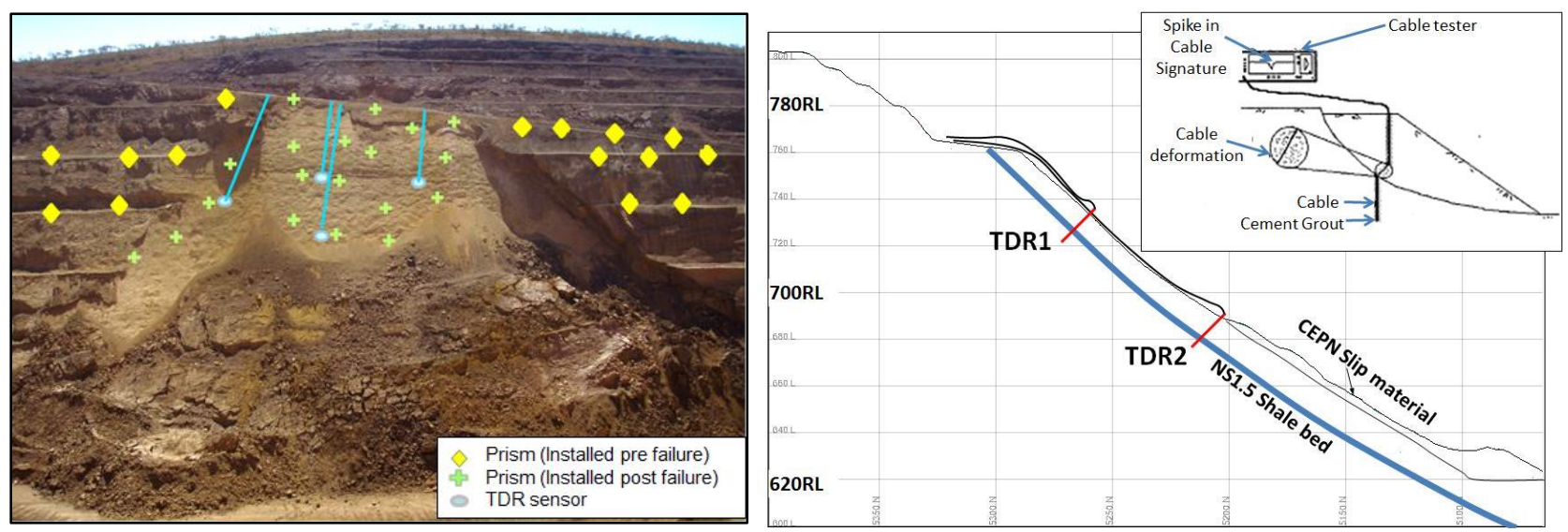

Figure 7 Slope monitoring installations on failure surface

\subsection{Mining the rill heap}

Prior to mining, the rill heap measured approximately $72 \mathrm{~m}$ high by $300 \mathrm{~m}$ long at the base and $150 \mathrm{~m}$ near the crest. Mining was planned using a staged and systematic approach and required close liaison between the geotechnical, mine operations and management teams. The initial mining plan consisted of the following steps (refer to Figure 8):

1. Use an excavator to establish an access ramp, towards the western side of the rill heap, through its shallowest section.

2. Excavator or dozer to ramp down to the west and establish permanent ramp from the $632 \mathrm{RL}$.

3. Excavator to ramp from east, removing and sidecasting all the rill above the ramp in the process.

4. Excavator to level the ramp off at $692 \mathrm{RL}$ and continue mining east to the 'no go' line.

5. Remotely operated dozers to sidecast material east of the eastern overhang 'no go' line down to the same level as the excavator pad. Mining west of the 'no go' line could not advance more than one flitch ahead of the remote dozing, otherwise access will be lost.

6. Use the excavator and dozer to sidecast the next flitch to the eastern overhang 'no go' line and widen the pad in the process.

7. Repeat steps 5 and 6 until mining completed.

8. Once the pad is sufficiently wide, start mining from the southern side on the $632 \mathrm{RL}$, taking care not to undermine where the excavator and dozer were working. 


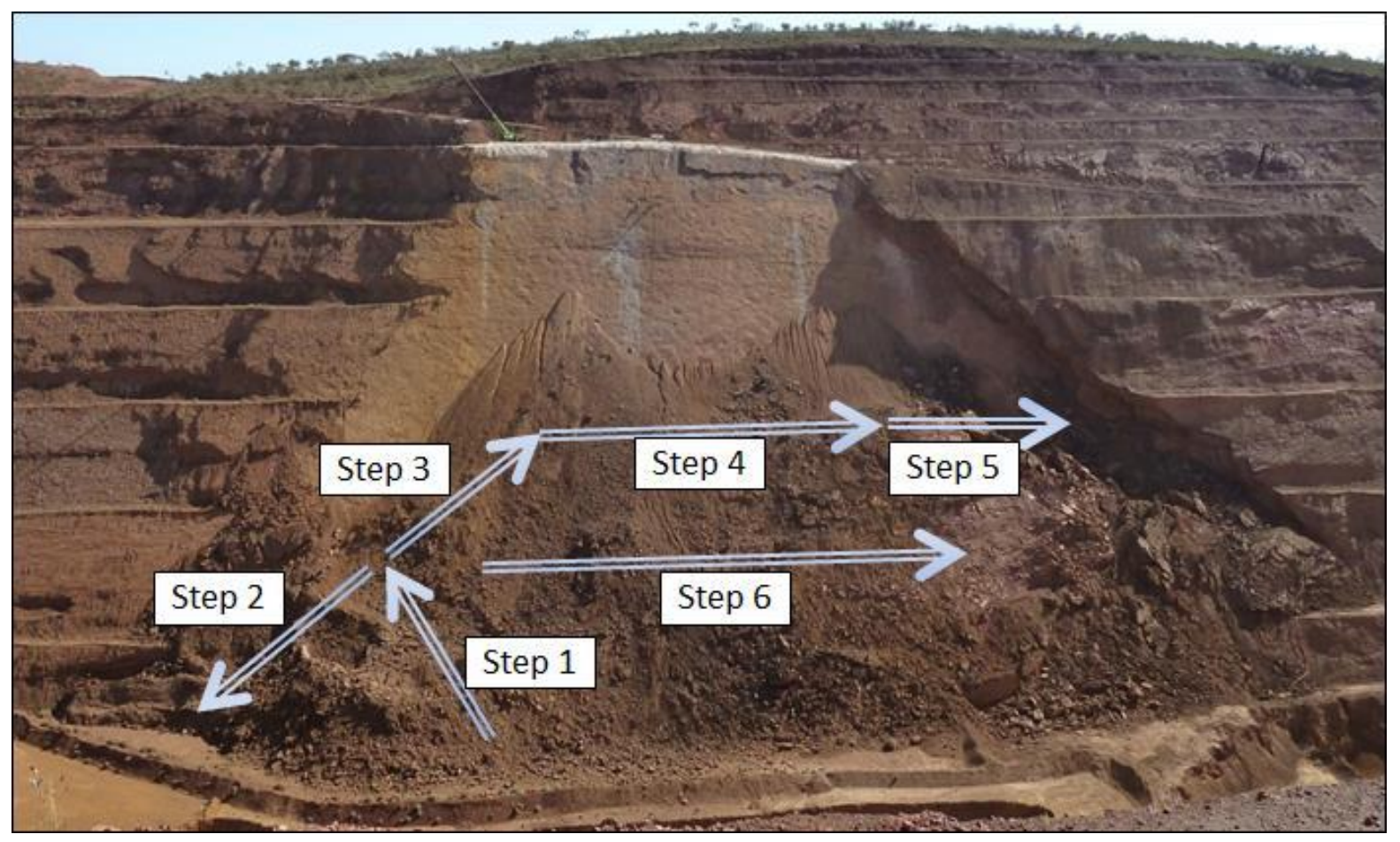

Figure 8 Proposed rill heap mining plan

A level 2 risk assessment was undertaken similar to the one completed for the rope work. Many of the risks and controls remained the same; however a number of new risks were identified which were unique to the mining process. New management strategies, JHA and TARP needed to be devised to incorporate these changes. The key hazards and controls are summarised in Table 2.

As the work progressed a number of challenges were encountered and deviations from the original plan became necessary. The risk management controls were consequently adapted to match these changing conditions. Close liaison with the project manager and production personnel was necessary throughout, to ensure the controls remained adequate and practical. To facilitate this geotechnical engineers attended daily pre-start meetings with the mine operations and specialist contractor teams.

\subsubsection{Monitoring observations}

Daily photographs of the slip and remediation area proved useful for planning the day to day mining activities at the morning pre-start meetings.

No concerning displacements were identified during the remediation and subsequent recovery mining. Additional prisms were installed on the slip face as mining of the rill heap progressed. Radar monitoring was also in place throughout the project and supported prism monitoring results.

TDR data was compared against previous traces, confirming that no adverse displacement was occurring on the deeper NS1.5 shale band. An example of representative prism and TDR observations is presented in Figure 9. 
Table 2 Mining related hazards and controls

\begin{tabular}{|c|c|}
\hline Hazard & Control \\
\hline $\begin{array}{l}\text { Rockfall hazard due to the excavator } \\
\text { working in close proximity to the slip } \\
\text { face which is in excess of } 100 \mathrm{~m} \text { high. }\end{array}$ & $\begin{array}{l}\text { Excavator to establish and maintain a catch trench and } \\
\text { windrow on the working pad, against the wall. }\end{array}$ \\
\hline $\begin{array}{l}\text { Potentially unstable outer edge of } \\
\text { working excavator pad in } \\
\text { unconsolidated material. }\end{array}$ & $\begin{array}{l}\text { Visual inspections and excavator to maintain } 5 \mathrm{~m} \text { clearance } \\
\text { between the crest and outside edge of tracks. }\end{array}$ \\
\hline $\begin{array}{l}\text { Rill material hanging up on the wall, } \\
\text { outside the reach of the excavator. }\end{array}$ & $\begin{array}{l}\text { Maintain the catch trench and windrow as mining of the first } \\
\text { flitch advances. Contractor to remove the hang-up by } \\
\text { scaling, before commencing the second flitch. }\end{array}$ \\
\hline $\begin{array}{l}\text { Insufficient material to construct a safe } \\
\text { pad on the target } R L \text { ( } 692 \mathrm{RL} \text { ) of the } \\
\text { first flitch. }\end{array}$ & $\begin{array}{l}\text { The excavator operator to determine the pad RL during } \\
\text { construction, based on maintaining a safe pad width. }\end{array}$ \\
\hline $\begin{array}{l}\text { Large rock slabs in rill heap may need } \\
\text { blasting. }\end{array}$ & $\begin{array}{l}\text { Blast patterns to be designed to minimise vibration and wall } \\
\text { damage. Blasting to be timed for end of day shift to allow } \\
12 \text { hours monitoring time before re-entry. Geotechnical } \\
\text { Engineers to monitor walls during blasting and advise if and } \\
\text { when it is safe to resume blasting. }\end{array}$ \\
\hline $\begin{array}{l}\text { Blasting east of eastern overhang 'no } \\
\text { go' line. }\end{array}$ & $\begin{array}{l}\text { Use autonomous drill. Minimise personnel access on foot. } \\
\text { Use autonomous dozer as mobile rockfall barrier to protect } \\
\text { personnel on foot. }\end{array}$ \\
\hline $\begin{array}{l}\text { Working close to walls means high } \\
\text { exposure to rockfall and fall of ground. }\end{array}$ & $\begin{array}{l}\text { Confine work to day shift only, when visibility is better and a } \\
\text { spotter can be used. }\end{array}$ \\
\hline $\begin{array}{l}\text { Mining out pad from base may } \\
\text { undercut and destabilise pad for } \\
\text { excavator and dozer. }\end{array}$ & $\begin{array}{l}\text { Delay mining until pad is lower and wider. Mining to take } \\
\text { place on night shift only, while remediation (sidecasting rill } \\
\text { pile) is on day shift only. }\end{array}$ \\
\hline $\begin{array}{l}\text { Excavator or dozer breaks down on } \\
\text { pad. }\end{array}$ & $\begin{array}{l}\text { If mobile, move off pad to safe location, or away from face. } \\
\text { Tow if necessary. }\end{array}$ \\
\hline $\begin{array}{l}\text { Breakdown of remote operated dozer } \\
\text { east of 'no go' line. }\end{array}$ & $\begin{array}{l}\text { Use second remote operated dozer to drag dozer clear of 'no } \\
\text { go' area. }\end{array}$ \\
\hline $\begin{array}{l}\text { Loss of radar monitoring or alarm } \\
\text { system. }\end{array}$ & $\begin{array}{l}\text { If still scanning, use spotter at radar until alarm system } \\
\text { repaired and fully functional. If not scanning, check other } \\
\text { monitoring and alarm systems, check for evidence of recent } \\
\text { movement, and for recent blasting or rainfall. If all OK, can } \\
\text { use alternate monitoring (autonomous prisms) for up to one } \\
\text { shift ( } 12 \text { hours). }\end{array}$ \\
\hline
\end{tabular}



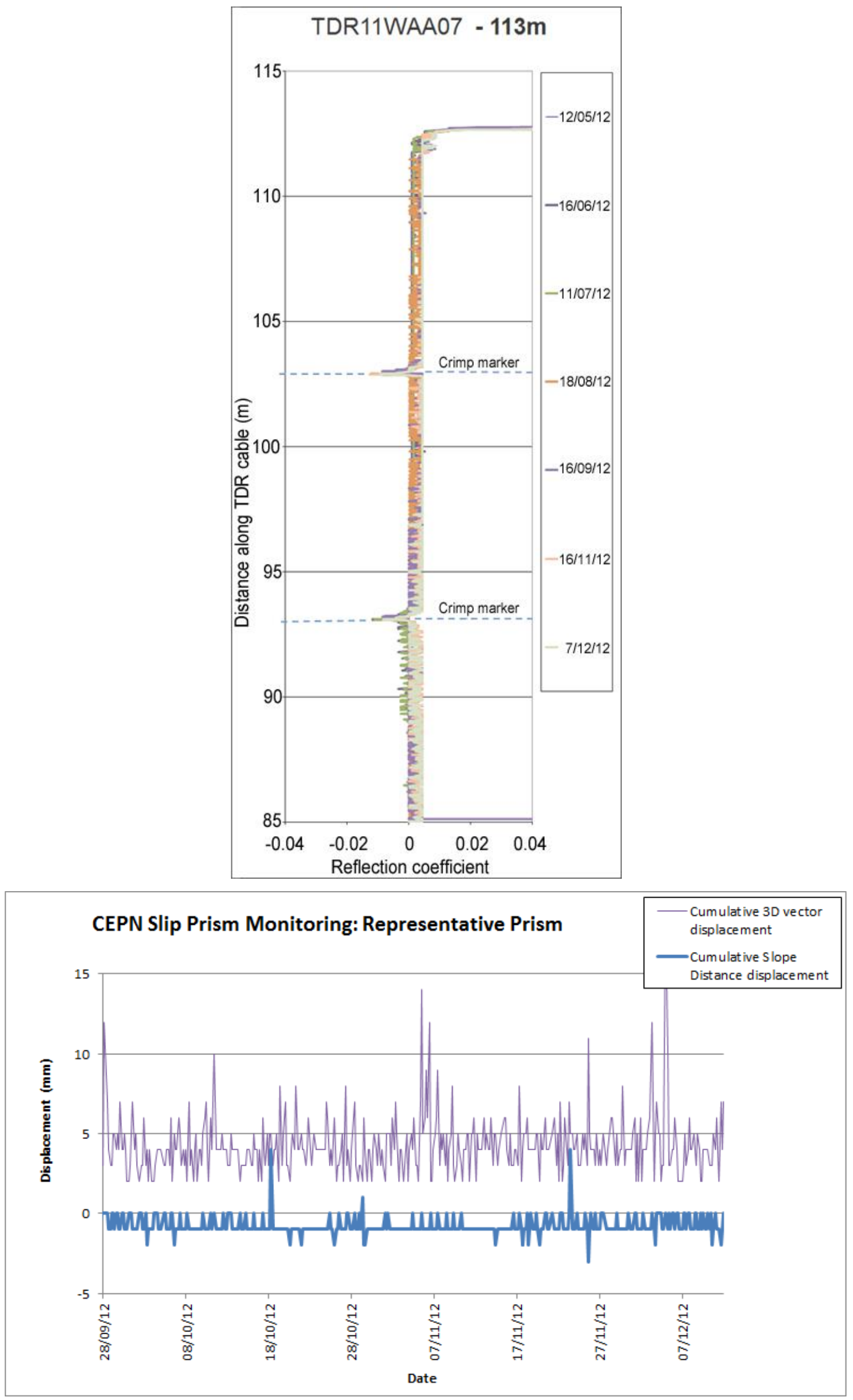

Figure 9 Prism 3 D vector and TDR data examples 


\subsubsection{Hard rock slabs}

The removal of the crest overhang and subsequent scaling activities covered many of the large rock slabs originally visible in the rill heap post failure. Photographs taken prior to the crest work were used to compare with the daily photographs to identify the likely location of the large rock slabs and scale of potential problems (Figure 10).

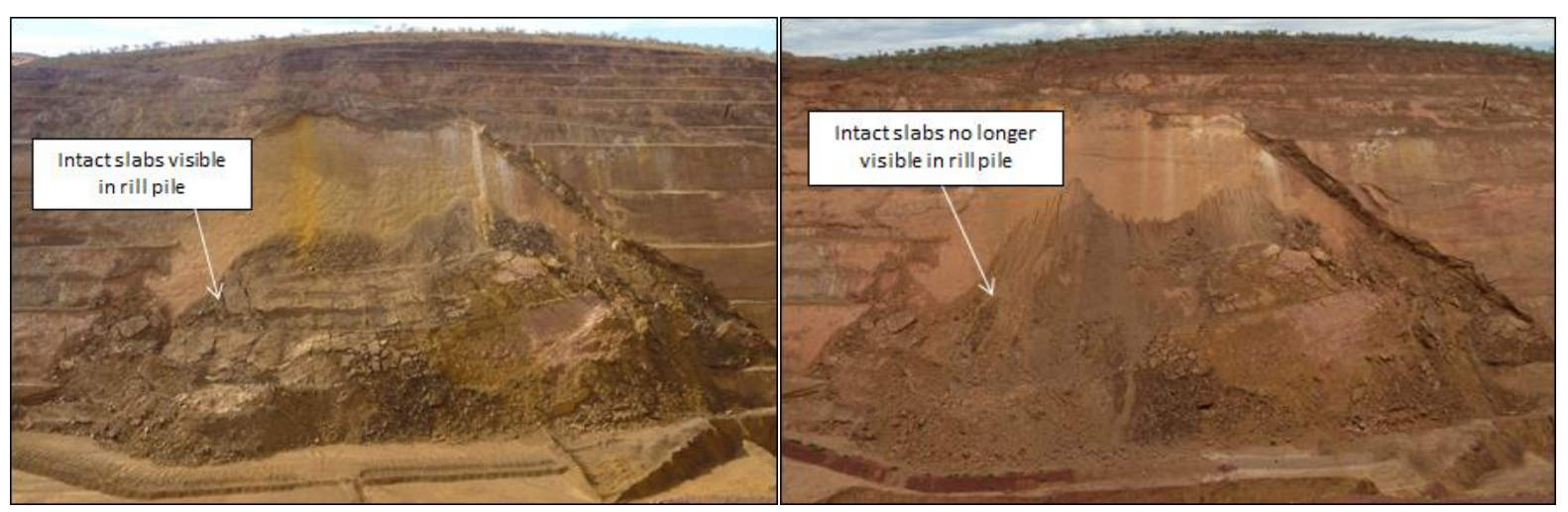

Figure 10 Changes to rill heap over time. Shortly after failure (left); after completion of crest work (right)

The first large rock was encountered towards the end of the step 1 ramp (Figure 11). In order to drill and blast the rock, it was necessary to move it to a flatter, more stable location. Attempts to dislodge it initially proved unsuccessful and left it undermined and a significant hazard to the development of the step 2 ramp to the west. It was therefore decided to bypass step 2 and start work on the step 3 ramp to the east, to allow the digger and dozer safer access to move it. This became unnecessary when the rock dislodged, before the pad could be constructed, and broke into smaller pieces in the process. No other large rocks were encountered while completing steps 2 and 3.

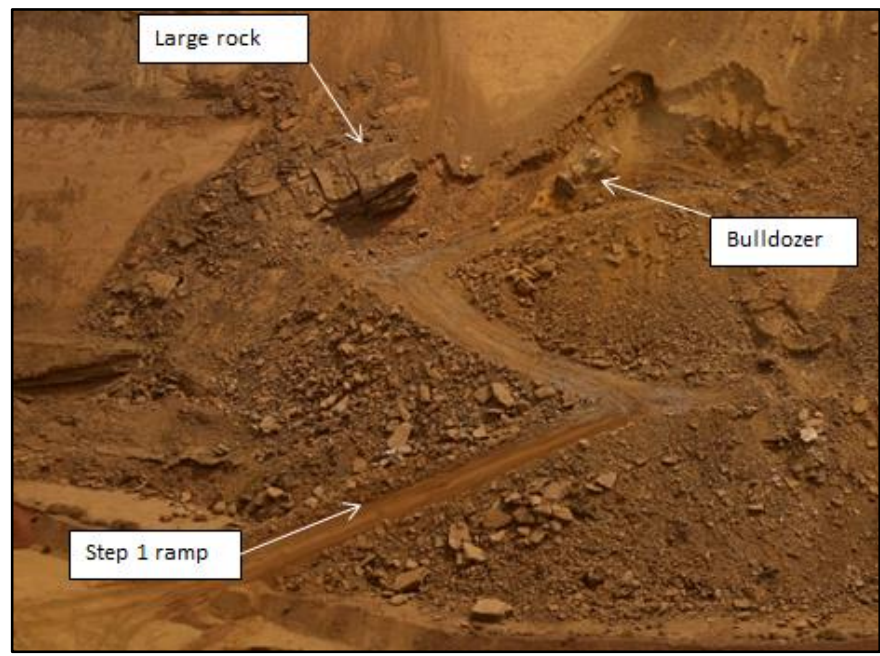

Figure 11 Large rock undercut by excavator. Dozer establishing digger pad for step 3 ramp

\subsubsection{Rill hang up}

A considerable amount of rill remained on the face out of reach of the excavator, as predicted during the risk assessment. This would pose an increasing rockfall hazard as mining progressed and the height to the hang up increased. The hazard was removed by hydraulic sluicing by lowering a pipe down the face to provide a directed flow of water onto the top of the rill. Flow rates were low, thus erosion of the face was not deemed to be an issue. The rill heap was free draining and the groundwater level was several metres below the pit floor. Stability analyses indicated that the sluicing activity would not have a detrimental impact on wall stability. Though effective, with the low flow rate it was very slow and it was difficult to 
position the pipe, which was controlled by two ropes running diagonally from opposite sides of the crest. Care had to be taken to avoid damaging the prism and TDR installations and to avoid getting caught on the rockbolts.

Approximately $70 \%$ of the rill hang up was removed by sluicing, however in order to accelerate the process, the contractor was engaged to use rope access to scale the last of the hang up (Figure 12).

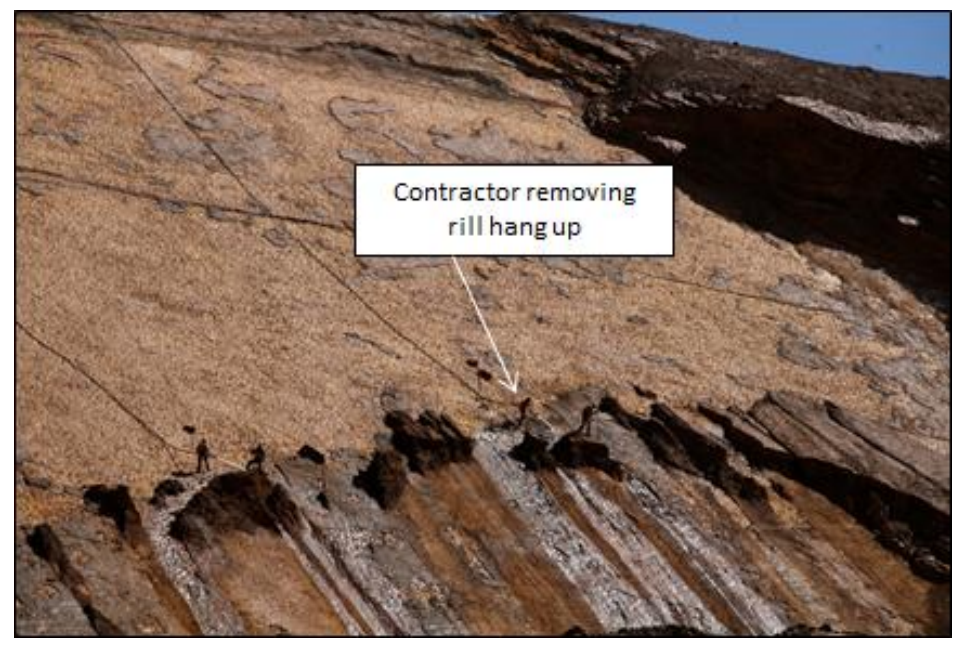

Figure 12 Rope access personnel sluicing and scaling the rill hang up

\subsubsection{Remote dozing}

Control of the remote dozers was originally attempted from the south wall, opposite the slip. The operator found that this did not provide sufficient visibility for the level of control required, particularly when working near the wall. The optimal position was found to be on the excavator pad, just outside the eastern overhang 'no go' line (Figure 13).

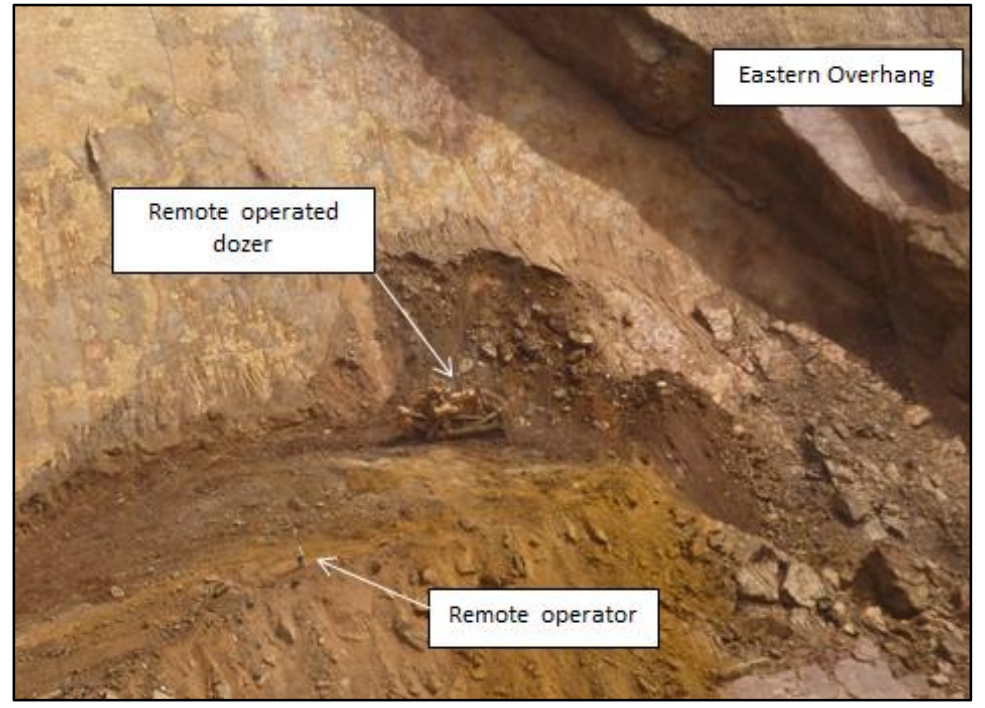

Figure 13 Remote dozer working below eastern overhang. Controller is stationed, outside 'no go' line

The top flitch was sidecast without incident. On the second flitch a large rock was encountered, which the remote dozer was unable to move. Although procedures had been prepared to facilitate drilling and blasting, the time required rather than the risks became the critical factor. Based on the initial, post failure photographs, it was assumed that more large rocks would be encountered and that the extra time required to drill and blast east of the 'no go' line would cause unacceptable delays in gaining access to the high 
grade ore. A management decision was made to cease works in this area and instead concentrate on recovering the bulk of the ore, west of the 'no go' line.

\subsubsection{Rock slab}

Another large slab of hard rock was encountered in the rill heap west of the 'no go' line, at the $680 \mathrm{RL}$, which could not be moved without blasting. It was critical to minimise the risk of blast damage to the face. The blast holes were designed with a minimum $3 \mathrm{~m}$ stand off from the slip face and were fired with reduced stemming and using electronic detonators to improve the timing and minimise vibration. The face and overhangs were monitored by the radar during the blast and overnight prior to work resuming. No significant movement was detected and no evidence of damage was observed to the slope.

\subsubsection{Sidecasting and mining}

By the time mining reached the $668 \mathrm{RL}$, the pad had widened sufficiently that some of the restrictions could be reviewed. The catch trench and windrow were maintained, sidecasting and mining could be carried out on day and night shift, so long as all work within $10 \mathrm{~m}$ of the face was done on day shift. Work was no longer required to stop if radar monitoring was lost for up to one 12 hour shift, but it was required that work not be undertaken within $10 \mathrm{~m}$ of the face. Light vehicles and personnel could access the excavator pad, maintaining a safe distance from working equipment. A $37^{\circ}$ rill slope was maintained against the material behind the 'no go' line. The TARP and associated documents were again revised to match the changing conditions.

\subsection{7 $\quad 644 R L$ and lower}

When mining reached the $644 \mathrm{RL}$ it was found that much of the berm was still intact. The pit design required a $15 \mathrm{~m}$ wide berm at the base of the slip face, the $644 \mathrm{RL}$ berm made up roughly half the required amount, the remainder of the $15 \mathrm{~m}$ was established on the $632 \mathrm{RL}$. A rockfall catch windrow was constructed behind the designed crest on the $632 \mathrm{RL}$, while mining of the high grade was underway (refer to Figure 14).

The radar remained in position, monitoring the north wall, until mining was completed at the $596 \mathrm{RL}$. In order to maximise ore recovery, the final cut on the south wall was designed as a triple batter with a mining slot only $50 \mathrm{~m}$ wide. In order to improve monitoring control of these risks, a second radar unit was deployed to monitor the south wall above this narrow mining slot. 


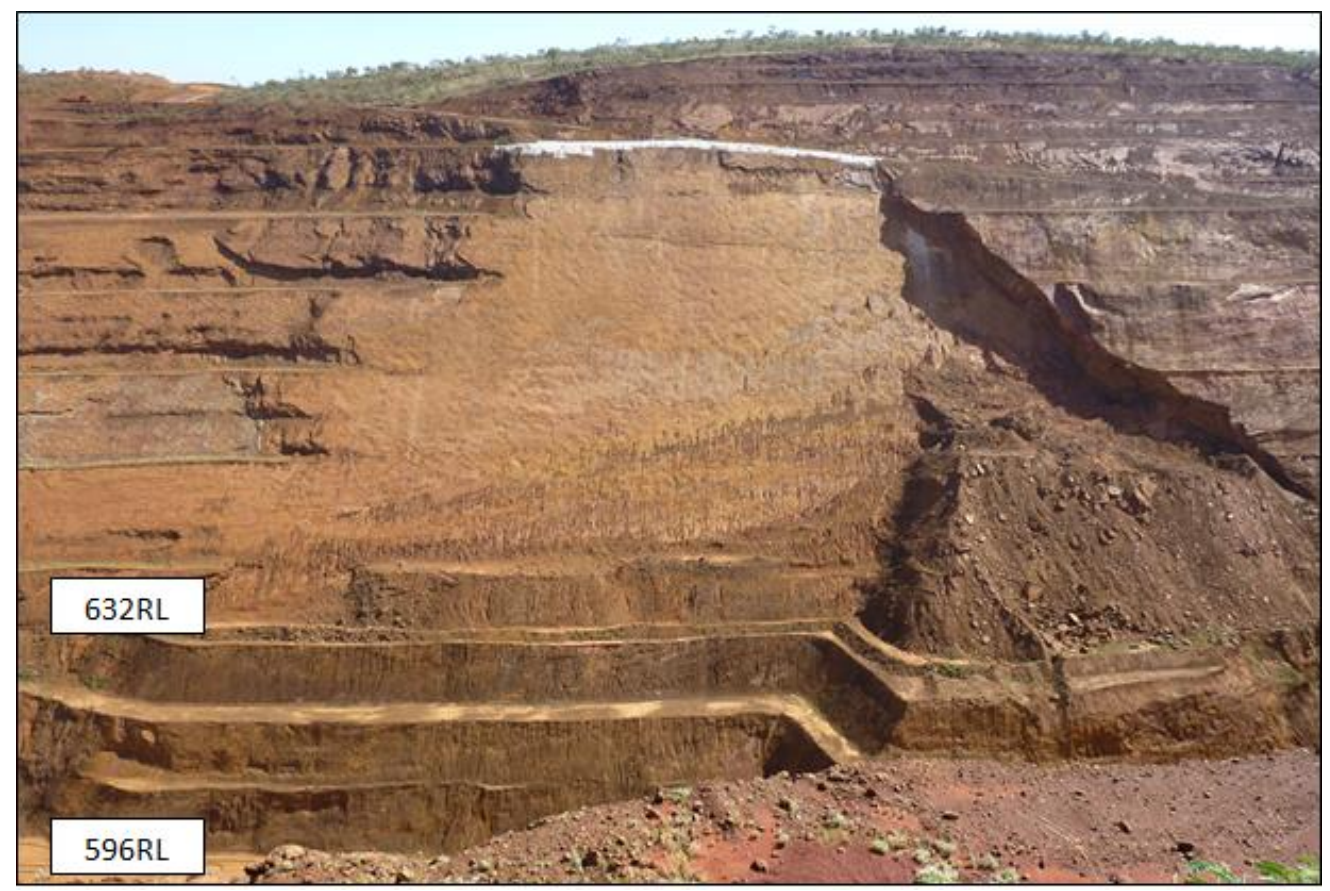

Figure 14 Slip remediation completed and high grade below $632 \mathrm{RL}$ recovered

\section{Conclusion}

Remediation work and mining the final wall below the CEPN north wall slip were completed at the end of 2012. The remediation work ultimately facilitated the recovery of approximately $80 \%$ of the high grade ore below and adjacent to the slip. The cost of the remediation was estimated to be $0.36 \%$ of the value of the ore recovered.

Despite the perceived high risk nature of the work, all risks associated with the project were managed successfully and without incident during the recovery process. The project also demonstrated to RTIO the value of rope access in slope stabilisation and monitoring gap applications.

\section{References}

Lopes, P.J.G. and Lee, T. (2013) Rockfall stabilisation of a steep and high slope at West Angelas mine using pre-tensioned anchored mesh, in Proceedings International Symposium on Slope Stability in Open Pit Mining and Civil Engineering (Slope Stability 2013), P.M Dight (ed), 25-27 September 2013, Brisbane, Australia, Australian Centre for Geomechanics, Perth, pp. 1261-1272. 